\title{
Antioxidant properties, anti-hepatocellular carcinoma activity and hepatotoxicity of artichoke, milk thistle and borututu
}

\author{
Carla Pereira ${ }^{\mathrm{a}}$, Ricardo C. Calhelha, ${ }^{\mathrm{a}, \mathrm{b}}$, Lillian Barros ${ }^{\mathrm{a},}$, \\ Isabel C.F.R. Ferreira, ${ }^{\mathrm{a},}$
}
${ }^{a}$ Centro de Investigação de Montanha (CIMO), ESA, Instituto Politécnico de Bragança, Campus de Santa Apolónia, apartado 1172, 5301-855 Bragança, Portugal
${ }^{\text {b} C e n t r o ~ d e ~ Q u i ́ m i c a, ~ U n i v e r s i d a d e ~ d o ~ M i n h o, ~ C a m p u s ~ d e ~ G u a l t a r ~ 4710-057 ~ B r a g a, ~}$ Portugal

* Authors to whom correspondence should be addressed (e-mail: iferreira@ipb.pt telephone +351-273-303219; fax +351-273-325405; email: lillian@ipb.pt; telephone +351-273-303200; fax +351-273-325405). 


\begin{abstract}
Cynara scolymus (artichoke), Silybum marianum (milk thistle) and Cochlospermum angolensis (borututu) are three plants widely used regarding hepatoprotective effects but to the best of our knowledge no anti-hepatocellular carcinoma activity has been studied in the most consumed forms: infusions and dietary supplements. Herein, antioxidant properties, anti-hepatocellular carcinoma activity and toxicity of infusions and dietary supplements of the mentioned plants were evaluated and compared. All the samples revealed antioxidant properties with $\mathrm{EC}_{50}$ values lower than the daily recommended dose, but infusions showed higher biological activity than dietary supplements. Borututu infusion gave the highest antioxidant activity $\left(\mathrm{EC}_{50} \leq 170 \mu \mathrm{g} / \mathrm{mL}\right)$, and also revealed anti-hepatocellular carcinoma activity $\left(\mathrm{GI}_{50}=146 \mu \mathrm{g} / \mathrm{mL}\right)$ without toxicity in non-tumour liver cells $\left(\mathrm{GI}_{50}>400 \mu \mathrm{g} / \mathrm{mL}\right)$. Artichoke infusion also presented antitumour activity $\left(\mathrm{GI}_{50}=52 \mu \mathrm{g} / \mathrm{mL}\right)$ but with toxicity for normal cells at a higher concentration $\left(\mathrm{GI}_{50}=72 \mu \mathrm{g} / \mathrm{mL}\right)$. The antioxidant and antitumour properties were positively correlated with phenolics and flavonoids content. Overall, among the three studied species, borututu infusion proved to be the most complete sample regarding antioxidant and antihepatocellular carcinoma activity.
\end{abstract}

Keywords: Medicinal plants; Infusions/Dietary supplements; Antioxidant activity; HepG2; toxicity 


\section{Introduction}

Artichoke (Cynara scolymus L.) is an herbaceous perennial plant native to the Mediterranean Basin that belongs to the Asteraceae family (Bianco, 2005). Consumed raw, boiled, steamed or fried, this plant is today widely cultivated all over the world for its large fleshy immature inflorescences, called heads or capitula, with edible leaves (bracts) and receptacle. Artichoke is known since ancient times as a tasty plant that can be used in soups, stews and salads, being perceived as a nutritious and healthy vegetable (Lattanzio et al., 2009) due to its antioxidant and hepatoprotective effects (Gebhardt and Fausel, 1997; Zapolska-Downar et al., 2002; Jimène-Escrig et al., 2003; Wang et al., 2003; Falleh et al., 2008; Kukić et al., 2008; Gouveia and Castilho, 2012). This plant contains very little fat and high levels of minerals, vitamin C, fibre, inulin, polyphenols hydoxycinnamates and flavones, but most of its activity could be related to the polyphenolic fraction, mainly composed of mono- and dicaffeoylquinic acids and flavonoids (Schütz et al., 2004; Falleh et al., 2008; Lutz et al., 2011; Pandino et al., 2011; Gouveia and Castilho, 2012).

Milk thistle (Silybum marianum (L.) Gaertn) is also a member of Asteraceae family. It's an annual to biennial herbaceous plant, native to the Mediterranean countries with reported effects against hepatotoxicity and acute and chronic liver diseases, due to its main pharmacological active ingredient silymarin (standard mixture of flavonoligans) (Giese, 2001; Zuber et al., 2002; Doehmer et al., 2011). Beyond the hepatoprotective activity, this flavonoid complex also has antioxidant properties which seem to be related to liver damage prevention (Nencini et al., 2007; Shaker et al., 2010). Silibinin, the major active constituent of silymarin, has been reported as inhibitor of tumour growth in 
hepatocarcinoma cell (Brandon-Warner et al., 2010) and animal (Bousserouel et al., 2012) models.

Borututu (Cochlospermum angolensis Welw.) is a widespread tree in Angola that belongs to the Cochlospermaceae family. Its bark infusion is used in the traditional medicine of Angola for the treatment of hepatic diseases and for the prophylaxis of malaria (Poppendieck, 1981; Presber et al., 1991; Silva et al., 2011). Phenolic composition of borututu hydromethanolic and aqueous extracts were recently characterized and revealed to be rich in methyl ellagic acid and ellagic acid, respectively (Ferreres et al., 2013). The infusion of its dry roots also showed high 2,2-diphenyl-1picrylhydrazyl (DPPH) scavenging activity (Costa et al., 2012).

Despite the described hepatoprotective effects of the three mentioned plants and a few reports on their anti-hepatocellular carcinoma activity (Miccadei et al., 2008; BrandonWarner et al., 2010), studies with the most consumed forms (infusions and dietary supplements) are scarce. Hepatocellular carcinoma is a major health problem with more than 660,000 new cases per year worldwide, being a rapid fatal disease with a life expectancy of about 6 months from the time of diagnostics; it has the third highest mortality rate among all cancers (Jemal et al., 2011). In the present work, infusions and dietary supplements of artichoke, milk thistle and borututu were prepared and studied for antioxidant properties, anti-hepatocellular carcinoma activity and hepatotoxicity in non-tumour liver primary cells. Furthermore, all these properties were correlated with the content in bioactive compounds.

\section{Material and Methods}




\subsection{Samples and samples preparation}

2.1.1. Samples. Cynara scolymus L. (artichoke), Silybum marianum (L.) Gaertn (milk thistle) and Cochlospermum angolensis Welw. (borututu) are plants widely used for their antioxidant and hepatoprotective properties. For the present study, artichoke, milk thistle and borututu were obtained from an herbalist shop in Bragança (Portugal), as dry material for infusions preparation (leaves, plant and bark, respectively; the taxonomical identification of plant species mentioned in the labels was confirmed) and dietary supplements (pills based-on plant and roots, in the case of borututu). All the samples were prepared according to the label and submitted to an evaluation of bioactive compounds (phenolics and flavonoids), antioxidant activity, anti-hepatocellular carcinoma activity and hepatotoxicity.

2.1.2. Infusions preparation. A dry weight of each material ( $20 \mathrm{~g}$ of artichoke and $8.5 \mathrm{~g}$ of milk thistle corresponding to the recommended 4 spoons; and $10 \mathrm{~g}$ of borututu) was added to $1 \mathrm{~L}$ or $0.5 \mathrm{~L}$ (in the case of borututu) of boiling distilled water, left to stand at room temperature for $10 \mathrm{~min}$, filtered under reduced pressure, frozen, lyophilized and redissolved in distilled water at a final concentration of $10 \mathrm{mg} / \mathrm{mL}$. The following dilutions were used in the biological assays: $10 \mathrm{mg} / \mathrm{mL}$ to $1.22 \mu \mathrm{g} / \mathrm{mL}$ for antioxidant activity assays; 400, 100, 25, 6.25 and $1.56 \mu \mathrm{g} / \mathrm{mL}$ for hepatotoxicity assays.

2.1.3. Dietary supplements preparation. Three pills of each sample $(1500 \mathrm{mg})$ were dissolved in $100 \mathrm{~mL}$ of distilled water (final concentration $15 \mathrm{mg} / \mathrm{mL}$ ). Several dilutions of each sample were prepared to perform further assays. The following dilutions were 
used in the biological assays: $15 \mathrm{mg} / \mathrm{mL}$ to $0.23 \mathrm{mg} / \mathrm{mL}$ for antioxidant activity assays; $400,100,25,6.25$ and $1.56 \mu \mathrm{g} / \mathrm{mL}$ for hepatotoxicity assays.

\subsection{Standards and reagents}

2,2-Diphenyl-1-picrylhydrazyl (DPPH) was obtained from Alfa Aesar (Ward Hill, USA). Gallic acid, catechin, trolox (6-hydroxy-2,5,7,8-tetramethylchroman-2carboxylic acid), ellipticine, phosphate buffered saline (PBS), acetic acid, sulforhodamine B (SRB), trichloroacetic acid (TCA) and Tris were purchased from Sigma (St. Louis, USA). Foetal bovine serum (FBS), L-glutamine, Hank's balanced salt solution (HBSS), trypsin-EDTA (ethylenediaminetetraacetic acid), nonessential amino acids solution $(2 \mathrm{mM})$, penicillin/streptomycin solution $(100 \mathrm{U} / \mathrm{mL}$ and $100 \mathrm{mg} / \mathrm{mL}$, respectively) and DMEM (Dulbecco's Modified Eagle Medium) were from Hyclone (Logan, USA). Water was treated in a Milli-Q water purification system (TGI Pure Water Systems, USA).

\subsection{Quantification of total bioactive compounds}

Total phenolics were estimated by Folin-Ciocalteu colorimetric assay according to procedures previously described (Batista et al., 2011) and the results were expressed as mg of gallic acid equivalents (GAE) per g of sample (lyophilized infusion or pill). Total flavonoids were determined by a colorimetric assay using aluminum trichloride, following procedures previously reported (Batista et al., 2011); the results were expressed as mg of $(+)$-catechin equivalents (CE) per $g$ of sample (lyophilized infusion or pill). 


\subsection{Evaluation of antioxidant activity}

The antioxidant properties were evaluated by four different tests as there is no universal method that can measure the antioxidant capacity of all samples accurately and quantitatively: DPPH radical-scavenging activity, reducing power, inhibition of $\beta$ carotene bleaching and inhibition of lipid peroxidation using TBARS (thiobarbituric acid reactive substances) in brain homogenates (Rafael et al., 2011). The results were expressed in $\mathrm{EC}_{50}$ values (sample concentration providing $50 \%$ of antioxidant activity or 0.5 of absorbance in the reducing power assay). Trolox was used as positive control.

2.4.1. DPPH radical-scavenging activity. This methodology was performed using an ELX800 microplate Reader (Bio-Tek Instruments, Inc; Winooski, USA). The reaction mixture on 96 well plate consisted in the sample solutions $(30 \mu \mathrm{L})$ and methanolic solution $(270 \mu \mathrm{L})$ containing DPPH radicals $\left(6 \times 10^{-5} \mathrm{~mol} / \mathrm{L}\right)$. The mixture was left to stand for $30 \mathrm{~min}$ in the dark, and the absorption was measured at $515 \mathrm{~nm}$. The radical scavenging activity (RSA) was calculated as a percentage of DPPH discoloration using the equation: $\% \mathrm{RSA}=\left[\left(\mathrm{A}_{\mathrm{DPPH}}-\mathrm{A}_{\mathrm{S}}\right) / \mathrm{A}_{\mathrm{DPPH}}\right] \times 100$, where $\mathrm{A}_{\mathrm{S}}$ is the absorbance of the solution containing the sample, and $\mathrm{A}_{\mathrm{DPPH}}$ is the absorbance of the DPPH solution.

2.4.2. Reducing power. The sample solutions $(0.5 \mathrm{~mL})$ were mixed with sodium phosphate buffer $(200 \mathrm{mmol} / \mathrm{L}, \mathrm{pH} 6.6,0.5 \mathrm{~mL})$ and potassium ferricyanide $(1 \% \mathrm{w} / \mathrm{v}$, $0.5 \mathrm{~mL})$. The mixture was incubated at $50{ }^{\circ} \mathrm{C}$ for $20 \mathrm{~min}$, and trichloroacetic acid $(10 \%$ w/v, $0.5 \mathrm{~mL})$ was added. The mixture $(0.8 \mathrm{~mL})$ was poured in the 48 wells plate, the same with deionised water $(0.8 \mathrm{~mL})$ and ferric chloride $(0.1 \% \mathrm{w} / \mathrm{v}, 0.16 \mathrm{~mL})$, and the absorbance was measured at $690 \mathrm{~nm}$ in the Microplate Reader mentioned above. 
2.4.3. Inhibition of $\beta$-carotene bleaching. A solution of $\beta$-carotene was prepared by dissolving $\beta$-carotene $(2 \mathrm{mg})$ in chloroform $(10 \mathrm{~mL})$. Two milliliters of this solution were pipetted into a round-bottom flask. The chloroform was removed at $40{ }^{\circ} \mathrm{C}$ under vacuum and linoleic acid (40 mg), Tween 80 emulsifier (400 mg), and distilled water $(100 \mathrm{~mL})$ were added to the flask with vigorous shaking. Aliquots $(4.8 \mathrm{~mL})$ of this emulsion were transferred into test tubes containing sample solutions $(0.2 \mathrm{~mL})$. The tubes were shaken and incubated at $50^{\circ} \mathrm{C}$ in a water bath. As soon as the emulsion was added to each tube, the zero time absorbance was measured at $470 \mathrm{~nm}$. $\beta$-Carotene bleaching inhibition was measured by the formula: $\beta$-carotene absorbance after 2h/initial absorbance) $\times 100$.

2.4.4. TBARS assay. Porcine (Sus scrofa) brains were obtained from official slaughtered animals, dissected, and homogenized with Polytron in an ice cold Tris-HCl buffer (20 $\mathrm{mM}, \mathrm{pH} 7.4$ ) to produce a $1: 2 \mathrm{w} / \mathrm{v}$ brain tissue homogenate which was centrifuged at $3000 \mathrm{~g}$ for $10 \mathrm{~min}$. An aliquot $(100 \mu \mathrm{L})$ of the supernatant was incubated with the sample solutions $(200 \mu \mathrm{L})$ in the presence of $\mathrm{FeSO}_{4}(10 \mathrm{mM} ; 100 \mu \mathrm{L})$ and ascorbic acid $(0.1 \mathrm{mM} ; 100 \mu \mathrm{l})$ at $37{ }^{\circ} \mathrm{C}$ for $1 \mathrm{~h}$. The reaction was stopped by the addition of trichloroacetic acid $(28 \% \mathrm{w} / \mathrm{v}, 500 \mu \mathrm{L})$, followed by thiobarbituric acid (TBA, 2\%, w/v, $380 \mu \mathrm{L}$ ), and the mixture was then heated at $80{ }^{\circ} \mathrm{C}$ for $20 \mathrm{~min}$. After centrifugation at $3000 \mathrm{~g}$ for $10 \mathrm{~min}$ to remove the precipitated protein, the color intensity of the malondialdehyde (MDA)-TBA complex in the supernatant was measured by its absorbance at $532 \mathrm{~nm}$. The inhibition ratio (\%) was calculated using the following 
formula: Inhibition ratio $(\%)=[(\mathrm{A}-\mathrm{B}) / \mathrm{A}] \times 100 \%$, where $\mathrm{A}$ and $\mathrm{B}$ were the absorbance of the control and the sample solution, respectively.

\subsection{Evaluation of hepatocellular carcinoma activity}

The anti-hepatocellular carcinoma activity was evaluated using HepG2, which is the most widely used tumour cell line and generally regarded as a good hepatocellular carcinoma model. HepG2 cells were routinely maintained as adherent cell cultures in DMEM supplemented with 10\% FBS, $2 \mathrm{mM}$ glutamine, $100 \mathrm{U} / \mathrm{mL}$ penicillin and 100 $\mathrm{mg} / \mathrm{mL}$ streptomycin, at $37{ }^{\circ} \mathrm{C}$, in a humidified air incubator containing $5 \% \mathrm{CO}_{2}$. The cell line was plated at $1.0 \times 10^{4}$ cells/well in 96 -well plates. Cells were then treated for $48 \mathrm{~h}$ with the sample solutions. Following this incubation period, the adherent cells were fixed by adding cold 10\% trichloroacetic acid (TCA, $100 \mu \mathrm{L})$ and incubated for $60 \mathrm{~min}$ at $4{ }^{\circ} \mathrm{C}$. Plates were then washed with deionized water and dried; sulforhodamine B solution $(0.1 \%$ in $1 \%$ acetic acid, $100 \mu \mathrm{L})$ was added to each plate well and incubated for $30 \mathrm{~min}$ at room temperature. Unbound SRB was removed by washing with $1 \%$ acetic acid. Plates were air dried, the bound SRB was solubilised with $10 \mathrm{mM}$ Tris (200 $\mu \mathrm{L}, \mathrm{pH}$ 7.4) and the absorbance was measured at $540 \mathrm{~nm}$ (Guimarães et al., 2013) in the microplate reader mentioned above. The results were expressed in $\mathrm{GI}_{50}$ values (sample concentration that inhibited $50 \%$ of the net cell growth). Ellipticine was used as positive control.

\subsection{Evaluation of hepatotoxicity}

The hepatotoxicity was accessed using a non-tumour liver primary culture established in our laboratory (PLP2). The cell culture was prepared from a freshly harvested porcine liver obtained from a local slaughter house. Once in the lab, the liver tissues were rinsed 
in Hank's balanced salt solution containing $100 \mathrm{U} / \mathrm{mL}$ penicillin, $100 \mu \mathrm{g} / \mathrm{mL}$ streptomycin and divided into $1 \times 1 \mathrm{~mm}^{3}$ explants. Five explants were placed in $25 \mathrm{~cm}^{2}$ tissue flasks in DMEM medium supplemented with 10\% FBS, 2 mM nonessential amino acids and $100 \mathrm{U} / \mathrm{mL}$ penicillin, $100 \mathrm{mg} / \mathrm{mL}$ streptomycin and incubated at $37^{\circ} \mathrm{C}$ with a humidified atmosphere containing $5 \% \mathrm{CO}_{2}$. The medium was changed every two days. Cultivation of the cells was continued with direct monitoring every two to three days using a phase contrast microscope. Before confluence, cells were subcultured and plated in 96-well plates at a density of $1.0 \times 10^{4}$ cells/well, and cultivated in DMEM medium with $10 \%$ FBS, $100 \mathrm{U} / \mathrm{mL}$ penicillin and $100 \mu \mathrm{g} / \mathrm{mL}$ streptomycin (Guimarães et al., 2013). Cells were treated for $48 \mathrm{~h}$ with the sample solutions and the same procedure described in the previous section for SRB assay was followed. The results were expressed in $\mathrm{GI}_{50}$ values (sample concentration that inhibited $50 \%$ of the net cell growth). Ellipticine was used as positive control.

\subsection{Statistical analysis}

For all the experiments three samples $(n=3)$ were analysed and all the assays were carried out in triplicate. The results are expressed as mean values and standard deviation (SD). The differences between the different samples were analyzed using one-way analysis of variance (ANOVA) followed by Tukey's honestly significant difference post hoc test with $\alpha=0.05$, coupled with Welch's statistic. This treatment was carried out using SPSS v. 18.0 program. The regression analysis between total phenolic or flavonoid contents, and antioxidant activity $\mathrm{EC}_{50}$ values and anti-hepatocellular carcinoma activity $\mathrm{GI}_{50}$ values used the same statistical package. 


\section{Results and Discussion}

\subsection{Bioactive compounds, antioxidant activity and hepatotoxicity of the infusions}

The results for infusions and dietary supplements are present in Tables $\mathbf{1}$ and $\mathbf{2}$, respectively. Borututu infusion gave the highest amounts of total phenolics and flavonoids, as also the highest antioxidant activity in all the assays (Table 1). The infusions of milk thistle and artichoke revealed, in general, similar contents in phenolics and antioxidant activity. The much higher content of total phenolics (132.26 mg GAE/g) and flavonoids (17.88 $\mathrm{mg} \mathrm{CE} / \mathrm{g})$ observed in borututu infusion might be related to the part of the plant used in this case (bark).

Although there are some reports on phenolics, flavonoids and DPPH scavenging activity of artichoke (Jimènez-Escrig et al., 2003; Falleh et al., 2008; Kubić et al., 2008; Lutz et al., 2011; Gouveia and Castilho, 2012), the studies were performed in extracts and not in the real forms of consumption (e.g. infusions and dietary supplements as herein). Data described in literature for methanolic extract $(15 \mathrm{mg} \mathrm{GAE} / \mathrm{g}$ dry weight, $9 \mathrm{mg}$ $\mathrm{CE} / \mathrm{g}$ and $\mathrm{DPPH} \mathrm{EC}_{50}=53 \mu \mathrm{g} / \mathrm{mL}$; Falleh et al., 2008), methanol:water (50:50, v:v) extract (50 mg GAE/g; Jimènez-Escrig et al., 2003), ethyl acetate extract (203 mg GAE $/ \mathrm{g}$ and $\mathrm{DPPH} \mathrm{EC}_{50}=22 \mu \mathrm{g} / \mathrm{mL}$; Kubić et al., 2008), buthanol extract (62 mg GAE/g and DPPH $\mathrm{EC}_{50}=127 \mu \mathrm{g} / \mathrm{mL}$; Kubić et al., 2008), ethanol extract (50 mg GAE/g and DPPH $\mathrm{EC}_{50}=157 \mu \mathrm{g} / \mathrm{mL}$; Kubić et al., 2008) and water extract (46 mg GAE/g and DPPH $\mathrm{EC}_{50}=173 \mu \mathrm{g} / \mathrm{mL}$; Kubić et al., 2008), indicate higher phenolics content and DPPH radical scavenging activity than the ones reported for the studied infusion. The opposite seem to be observed by Gouveia and Castilho (2012) in ultrasound-assisted methanolic extract ( $0.23 \mathrm{mg} \mathrm{GAE} / \mathrm{g})$ and by Lutz et al. (2011) in aqueous and hydroalcoholic extracts $(\sim 30 \%$ of DPPH scavenging activity). 
Nevertheless, it should be highlighted that most of the mentioned solvents present toxicity and do not mimetize the most consumed forms as previously stated.

Costa et al. (2012) also described phenolics, flavonoids and DPPH scavenging activity in borututu infusion $(1.4 \mathrm{mg}$ GAE/100 mL, $0.34 \mathrm{mg}$ epicatechin equivalents $/ 100 \mathrm{~mL}$ and $\mathrm{DPPH} \mathrm{EC}_{50}=1.9 \mathrm{mg}$ trolox equivalents $/ 100 \mathrm{~mL}$ ).

In the present work, artichoke and borututu infusions demonstrated anti-hepatocellular carcinoma activity with $\mathrm{GI}_{50}$ values of 52 and $146 \mu \mathrm{g} / \mathrm{mL}$, respectively, but artichoke showed toxicity in normal cells $(72 \mu \mathrm{g} / \mathrm{mL})$. Despite the lower activity of borututu infusion, this sample did not show any hepatotoxicity in normal cells $\left(\mathrm{GI}_{50}>400\right.$ $\mu \mathrm{g} / \mathrm{mL}$ ); milk thistle also did not reveal toxicity in normal liver cells (Table 1).

As can be observed in Table 3, the bioactive properties (antioxidant and antitumour) of the infusions were positively correlated $(p<0.05)$ with phenolics and flavonoids content.

\subsection{Bioactive compounds, antioxidant activity and hepatotoxicity of the dietary} supplements

Regarding dietary supplements, the amount of bioactive compounds and the degree of antioxidant activity was as follows: borututu $>$ milk thistle $>$ artichoke. These samples neither revealed anti-hepatocelullar carcinoma activity (HepG2 $\mathrm{GI}_{50}$ value $>400 \mu \mathrm{g} / \mathrm{mL}$ ), nor toxicity for normal liver cells (PLP2 $\mathrm{GI}_{50}$ value $>400 \mu \mathrm{g} / \mathrm{mL}$ ) (Table 2).

The biological activity of the dietary supplements was positively correlated $(p<0.05)$ with the total phenolics and flavonoids content (Table 3), with the exception of phenolics/DPPH scavenging activity, flavonoids/reducing power and flavonoids/TBARS inhibition correlations. 
Overall, all the samples revealed antioxidant properties with $\mathrm{EC}_{50}$ values lower than the daily recommended dose, but infusions showed higher antioxidant activity than dietary supplements. This in agreement with Gouveia and Castilho (2012) that reported a decrease in antioxidant potential of artichoke dietary supplements due to the absence of phenolic compounds. Borututu infusion gave the highest antioxidant activity, and also revealed anti-hepatocellular carcinoma activity without toxicity in non-tumour liver cells. On the contrary, artichoke infusion presented the highest antitumour activity but with toxicity for normal cells.

\section{Acknowledgements}

The authors are grateful to the Foundation for Science and Technology (FCT, Portugal) for financial support to the research centre CIMO (PEst-OE/AGR/UI0690/2011). L. Barros also thanks to FCT, POPH-QREN and FSE for her grant (SFRH/BPD/4609/2008).

\section{References}

Bianco, V. 2005. Present situation and future potential of artichoke in the Mediterranean basin. Acta Hort. 681, 39-55.

Bousserouel, S., Bour, G., Kauntz, H., Gosse, F., Marescaux, J., Raul, F. 2012. Silibinin inhibits tumor growth in a murine orthotopic hepatocarcinoma model and activates the TRAIL apoptotic signaling pathway. Anticancer Res. 32, 2455-2462. 
Brandon-Warner, E., Sugg, J.A., Schrum, L.W., McKillop, I.H. 2010. Silibinin inhibits ethanol metabolism and ethanol-dependent cell proliferation in an in vitro model of hepatocellular carcinoma. Cancer Lett. 291, 120-129.

Costa, A.S.G., Nunes, M.A., Almeida, I.M.C., Carvalho, M.R., Barroso, M.F., Alves, R.C., Oliveira, M.B.P.P. 2012. Teas, dietary supplements and fruit juices: A comparative study regarding antioxidant activity and bioactive compounds. LWT 49, 324-328.

Doehmer, J., Weiss, G., McGregor, G.P., Appel, K. 2011. Assessment of a dry extract from milk thistle (Silybum marianum) for interference with human liver cytochrome-P450 activities. Toxicol. Vitro 25, 21-27.

Falleh, H., Ksouri, R., Chaieb, K., Karray-Bouraoni, N., Trabelsi, N., Boulaaba, M., Abdelly, C. 2008. Phenolic composition of Cynara cardunculus L. organs, and their biological activities. C.R. Biologies 331, 372-379.

Ferreres, F., Grosso, C., Gil-Izquierdo, A., Valentão, P., Andrade, P. 2013. Ellagic acid and derivatives from Cochlospermum angolensis Welw. extracts: HPLC-DAD$\mathrm{ESI} / \mathrm{MS}^{\mathrm{n}}$ profiling, quantification and in vitro anti-depressant, anti-cholinesterase and anti-oxidant activities. Phytochem. Anal. DOI: 10.1002/pca.2429.

Gebhardt, R., Fausel, M. 1997. Antioxidant and hepatoprotective effects of artichoke extracts and constituents in cultured rat hepatocytes. Toxicol. Vitro. 11, 669-672.

Giese, L.A. 2001. Milk thistle and the treatment of hepatitis. Gastroenterol. Nurs. 24, 95-97.

Gouveia, S.C., Castilho, P.C. 2012. Phenolic composition and antioxidant capacity of cultivated artichoke, Madeira cardoon and artichoke-based dietary supplements. Food Res. Int. 48, 712-724. 
Guimarães, R., Barros, L., Dueñas, M., Calhelha, R.C., Carvalho, A.M., Santos-Buelga, C., Queiroz, M.J.R.P.Q., Ferreira, I.C.F.R. 2013. Nutrients, phytochemicals and bioactivity of wild Roman chamomile: a comparison between the herb and its preparations. Food Chem. 136, 718-725.

Jemal, A., Bray, F., Center, M.M., Ferlay, J., Ward, E., Forman, D. 2011. Global Cancer Statistics. Cancer J. Clin. 61, 69-90.

Jimènez-Escrig, A., Dragsted, L.O., Daneshvar, B., Pulido, R., Saura-Calixto, F. 2003. In vitro antioxidant activities of edible artichoke (Cynara scolymus L.) and effect on biomarkers of antioxidants in rats. J. Agric. Food Chem. 51, 5540-5545.

Kukić, J., Popović, V., Petrović, S., Mucaji, P., Ćirić, A., Stojković, D., Soković, M. 2008. Antioxidant and antimicrobial activity of Cynara cardunculus extracts. Food Chem. 107, 861-868.

Lattanzio, V., Kroon, P.A., Linsalata, V., Cardinali, A. 2009. Global artichoke: A functional food and source of nutraceutical ingredients. J. Func. Foods I, 131-144.

Lutz, M., Henríquez, C., Escobar, M. 2011. Chemical composition and antioxidant properties of mature and baby artickokes (Cynara cardunculus L.), raw and cooked. J. Food Compos. Anal. 24, 49-54.

Miccadei, S., Di Venere, D., Cardinali, A., Romano, F., Durazzo, A., Foddai, M.S., Fraioli, R., Mobarhan, S., Maiani, G. 2008. Antioxidative and apoptotic properties of polyphenolic extracts from edible part of artichoke (Cynara scolymus L.) on cultured rat hepatocytes and on human hepatoma cells. Nutr. Cancer 60, 276-283.

Nencini, C., Giorgi, G., Micheli, L. 2007. Protective effect of silymarin on oxidative stress in rat brain. Phytomedicine 14, 129-135. 
Pandino, G., Lombardo, S., Mauromicale, G., Williamson, G. 2011. Phenolic acids and flavonoids in leaf and floral stem of cultivated and wild Cynara cardunculus L. genotypes. Food Chem. 126, 417-422.

Poppendieck, H.-H. 1981 Cochlospermaceae, New York Botanical Gardens, Bronx, NY.

Presber, W., Herrman, D.K., Hegenscheid, B. 1991. The effect of an extract from Cochlospermum angolense ('Burututu') on Plasmodium berghei in the mouse malaria suppression test. Angewandte Parasitologie, 32, 7-9.

Rafael, M., Barros, L., Carvalho, A.M., ferreira I.C.F.R. 2011. Topical antiinflammatory plant species: Bioactivity of Bryonia dioica, Tamus communis and Lonicera peryclimenum fruits. Ind. Crops Prod. 34, 1447- 1454

Schütz, K., Kammerer, D., Carle, R., Schieber, A. 2004. Identification and quantification of caffeoylquinic acids and flavonoids from artichoke (Cynara scolymus L.) heads, juice, and pomace by HPLC-DAD-ESI/MSn. J. Agric. Food Chem. 52, 4090-4096.

Shaker, E., Mahmoud, Mnaa, S. 2010. Sylmarin, the antioxidant component and Silybum marianum extract prevent liver damage. Food Chem Toxicol. 48, 803806.

Silva, J.R.A., Ramos, A.S., Machado, M., Moura, D.F., Neto, Z., Canto-Cavalheiro, M.M., Figueiredo, P., Rosario, V.E., Amaral, A.C.F., Lopes, D. 2011. A review of antimalarial plants used in traditional medicine in communities in Portuguese speaking countries: Brazil, Mozambique, Cape Verde, Guinea-Bissau, Sao Tome and Principe and Angola. Mem. Inst. Oswaldo Cruz 106, 142-158. 
Wang, M., Simon, J.E., Aviles, I.F., He, K., Zheng, Q., Tadmor, Y. 2003. Analysis of antioxidative phenolic compounds in artichoke (Cynara scolymus L.). J. Agric. Food Chem. 51, 601-608.

Zapolska-Downar, D., Zapolska-Downar, A., Naruszewicz, M., Siennicka, A., Krasnodebska, B., Kolodziej, B. 2002. Protective properties of artichoke (Cynara scolymus) against oxidative stress induced in cultured endothelial cells and monocytes. Life Sci. 71, 2897-2908.

Zuber, R., Modriansky, M., Dvorak, Z., Rohovsky, P., Urichova, J., Simanek, V. 2002. Effect of silybin and its congeners on human liver microsomal cytochrome P450 activities. Phytother. Res. 16, 632-638. 
Table 1. Bioactive compounds, antioxidant activity and hepatotoxicity of the infusions.

$\begin{array}{cccc}\text { Cynara scolymus } & \text { Silybum marianum } & \text { Cochlospermum angolensis } & \text { Positive } \\ \text { (Artichoke) } & \text { (Milk thistle) } & \text { (Borututu) } & \text { control }^{*}\end{array}$

Bioactive compounds

Total phenolics (mg GAE/g)

$20.82 \pm 0.10^{b}$

$23.26 \pm 0.22^{b}$

$132.26 \pm 1.04^{\mathrm{a}}$

Total flavonoids (mg CE/g)

$4.37 \pm 0.05^{\mathrm{c}}$

$6.95 \pm 0.23^{b}$

$17.88 \pm 0.22^{\mathrm{a}}$

Antioxidant activity $\left(\mathrm{EC}_{50}\right.$ values, $\left.\mathrm{mg} / \mathrm{mL}\right)$

DPPH scavenging activity

$2.13 \pm 0.41^{\mathrm{a}}$

$2.45 \pm 0.18^{\mathrm{a}}$

$0.15 \pm 0.01^{\mathrm{b}}$

$0.04 \pm 0.00$

Reducing power

$1.81 \pm 0.07^{\mathrm{a}}$

$1.73 \pm 0.03^{\mathrm{a}}$

$0.17 \pm 0.00^{\mathrm{b}}$

$0.03 \pm 0.00$

$\beta$-carotene bleaching inhibition

$1.69 \pm 0.19^{\mathrm{a}}$

$1.36 \pm 0.08^{\mathrm{b}}$

$0.62 \pm 0.10^{\mathrm{c}}$

$0.003 \pm 0.00$

TBARS inhibition

$0.14 \pm 0.00^{\mathrm{b}}$

$0.35 \pm 0.00^{\mathrm{a}}$

$0.02 \pm 0.00^{\mathrm{c}}$

$0.004 \pm 0.00$

Anti-hepatocellular carcinoma activity $\left(\mathrm{GI}_{50}\right.$ values, $\left.\mu \mathrm{g} / \mathrm{mL}\right)$

HepG2 (hepatocellular carcinoma)

$52.06 \pm 4.62^{\mathrm{b}}$

$>400$

$146.06 \pm 10.58^{\mathrm{a}}$

$3.22 \pm 0.67$

Hepatotoxicity ( $\mathrm{GI}_{50}$ values, $\mu \mathrm{g} / \mathrm{mL}$ )

PLP2 (non-tumour liver primary culture)

$71.73 \pm 5.88$

$>400$

$>400$

$2.06 \pm 0.03$

*Trolox and ellipticine for antioxidant and hepatotoxicity assays, respectively. $\mathrm{EC}_{50}$ values correspond to the sample concentration achieving 50\% of antioxidant activity or 0.5 of absorbance in reducing power assay. $\mathrm{GI}_{50}$ values correspond to the sample concentration achieving 50\% of growth inhibition in HepG2 human hepatocellular carcinoma cell line or in liver primary culture PLP2. In each row different letters mean significant differences $(\mathrm{p}<0.05)$. 
Table 2. Bioactive compounds, antioxidant activity and hepatotoxicity of the dietary supplements.

$\begin{array}{cccc}\text { Cynara scolymus } & \text { Silybum marianum } & \text { Cochlospermum angolensis } & \text { Positive } \\ \text { (Artichoke) } & \text { (Milk thistle) } & \text { (Borututu) } & \text { control }^{*}\end{array}$

Bioactive compounds

Total phenolics (mg GAE/g)

$3.35 \pm 0.01^{\mathrm{c}}$

$20.92 \pm 0.45^{\mathrm{b}}$

$30.70 \pm 0.79^{\mathrm{a}}$

Total flavonoids (mg CE/g)

$2.83 \pm 0.10^{\mathrm{c}}$

$3.88 \pm 0.13^{b}$

$5.65 \pm 0.03^{\mathrm{a}}$

Antioxidant activity $\left(\mathrm{EC}_{50}\right.$ values, $\left.\mathrm{mg} / \mathrm{mL}\right)$

DPPH scavenging activity

$10.14 \pm 0.58^{\mathrm{a}}$

$8.18 \pm 0.46^{\mathrm{b}}$

$1.27 \pm 0.01^{\mathrm{c}}$

$0.04 \pm 0.00$

Reducing power

$2.28 \pm 0.09^{\mathrm{a}}$

$1.10 \pm 0.02^{\mathrm{b}}$

$0.58 \pm 0.01^{\mathrm{c}}$

$0.03 \pm 0.00$

$\beta$-carotene bleaching inhibition

n.p.

$17.72 \pm 0.57^{\mathrm{a}}$

$5.62 \pm 0.66^{\mathrm{b}}$

$0.003 \pm 0.00$

TBARS inhibition

$1.49 \pm 0.05^{\mathrm{a}}$

$0.78 \pm 0.03^{\mathrm{b}}$

$0.34 \pm 0.05^{\mathrm{c}}$

$0.004 \pm 0.00$

Anti-hepatocellular carcinoma activity ( $\mathrm{GI}_{50}$ values, $\mu \mathrm{g} / \mathrm{mL}$ )

HepG2 (hepatocellular carcinoma)

$>400$

$>400$

$>400$

$3.22 \pm 0.67$

Hepatotoxicity ( $\mathrm{GI}_{50}$ values, $\mu \mathrm{g} / \mathrm{mL}$ )

PLP2 (non-tumour liver primary culture)

$>400$

$>400$

$>400$

$2.06 \pm 0.03$

*Trolox and ellipticine for antioxidant and hepatotoxicity assays, respectively. $\mathrm{EC}_{50}$ values coirespond to the sample concentration achieving $50 \%$ of antioxidant activity or 0.5 of absorbance in reducing power assay. $\mathrm{GI}_{50}$ values correspond to the sample concentration achieving 50\% of growth inhibition in HepG2 human hepatocellular carcinoma cell line or in liver primary culture PLP2. n.p.- not possible to determine. In each row different letters mean significant differences $(\mathrm{p}<0.05)$. 
Table 3. Correlations established between total phenolics, total flavonoids, antioxidant activity $\mathrm{EC}_{50}$ values and anti-hepatocellular carcinoma activity $\mathrm{GI}_{50}$ values of the infusions and dietary supplements.

\begin{tabular}{|c|c|c|c|c|c|}
\hline & & \multicolumn{2}{|l|}{ Infusions } & \multicolumn{2}{|l|}{ Dietary supplements } \\
\hline & & Phenolics (mg GAE/g) & Flavonoids (mg CE/g) & Phenolics (mg GAE/g) & Flavonoids (mg CE/g) \\
\hline DPPH scavenging activity & Linear equation & $Y=-0.0194 x+2.7156$ & $Y=-0.1653 x+3.1871$ & $Y=0.626 x+2.445$ & $Y=15.319 x-56.167$ \\
\hline $\mathrm{EC}_{50}$ value $(\mathrm{mg} / \mathrm{mL})$ & $\mathrm{R}^{2}$ & 0.9246 & 0.8570 & 0.3078 & 0.9288 \\
\hline Reducing power & Linear equation & $Y=-0.0144 x+2.0805$ & $Y=-0.1266 x+2.4657$ & $Y=-0.0498 x+2.2389$ & $Y=-0.0289 x+1.4481$ \\
\hline $\mathrm{EC}_{50}$ value $(\mathrm{mg} / \mathrm{mL})$ & $\mathrm{R}^{2}$ & 0.9970 & 0.9774 & 0.6047 & 0.3001 \\
\hline$\beta$-carotene bleaching inhibition & Linear equation & $Y=-0.0083 x+1.7099$ & $Y=-0.0757 x+1.9611$ & $Y=1.2166 x-19.730$ & $Y=6.7664 x-20.581$ \\
\hline $\mathrm{EC}_{50}$ value $(\mathrm{mg} / \mathrm{mL})$ & $\mathrm{R}^{2}$ & 0.8551 & 0.9117 & 0.9718 & 0.9861 \\
\hline TBARS inhibition & Linear equation & $Y=-0.0004 x+0.0563$ & $Y=-0.0041 x+0.0719$ & $Y=-0.0426 x+1.6595$ & $Y=-0.3914 x+2.6643$ \\
\hline $\mathrm{EC}_{50}$ value $(\mathrm{mg} / \mathrm{mL})$ & $\mathrm{R}^{2}$ & 0.5447 & 0.6874 & 0.9885 & 0.4208 \\
\hline HepG2 & Linear equation & $Y=0.8434 x+34.512$ & $Y=6.9512 x+21.71$ & - & - \\
\hline $\mathrm{GI}_{50}$ value $(\mu \mathrm{g} / \mathrm{mL})$ & $\mathrm{R}^{2}$ & 0.9899 & 0.9892 & - & - \\
\hline
\end{tabular}

